\title{
A Note on Determining Soil Properties for Soils Containing Rock Fragments
}

\section{D.L. BRAKENSIEK, W.J. RA WLS, AND G.R. STEPHENSON}

Many rangeland soils contain a significant rock fraction which may modify soil properties, whereas most published soil and soil

Authors are research hydraulic engineer, USDA-ARS, Northwest Watershed Research Center, Boise, Ida. 83705; hydrologist USDA-ARS, Hydrology Laboratory, Beltsville, Md. 20705; and geologist, USDA-ARS, Northwest Watershed Research Center, Boise, Ida. 83705.

The report is a contibution from the USDA-ARS, Northwest Watershed Research Center, 270 South Orchard, Boise, Ida. 83705 and Hydrology Laboratory, Rm. 139 Bg. 007, BARC-West, Beltsville, Md. 20705.

Manuscript accepted 26 December 1985.

Table 1. Soil and water properties. water data are for the fine earth fraction. A listing of equations is presented which calculates soil water properties for soils containing a rock fraction. It is seen that standardization is badly needed to describe properties of these soils. Especially needed is standardization to distinguish between bulk densities and particle densities as well as properties on a mass or volume basis. The classification of these soils is discussed by Miller and Guthrie (1984).

Table 1 presents published or derived equations for some common soil and water properties. Most of these relationships were

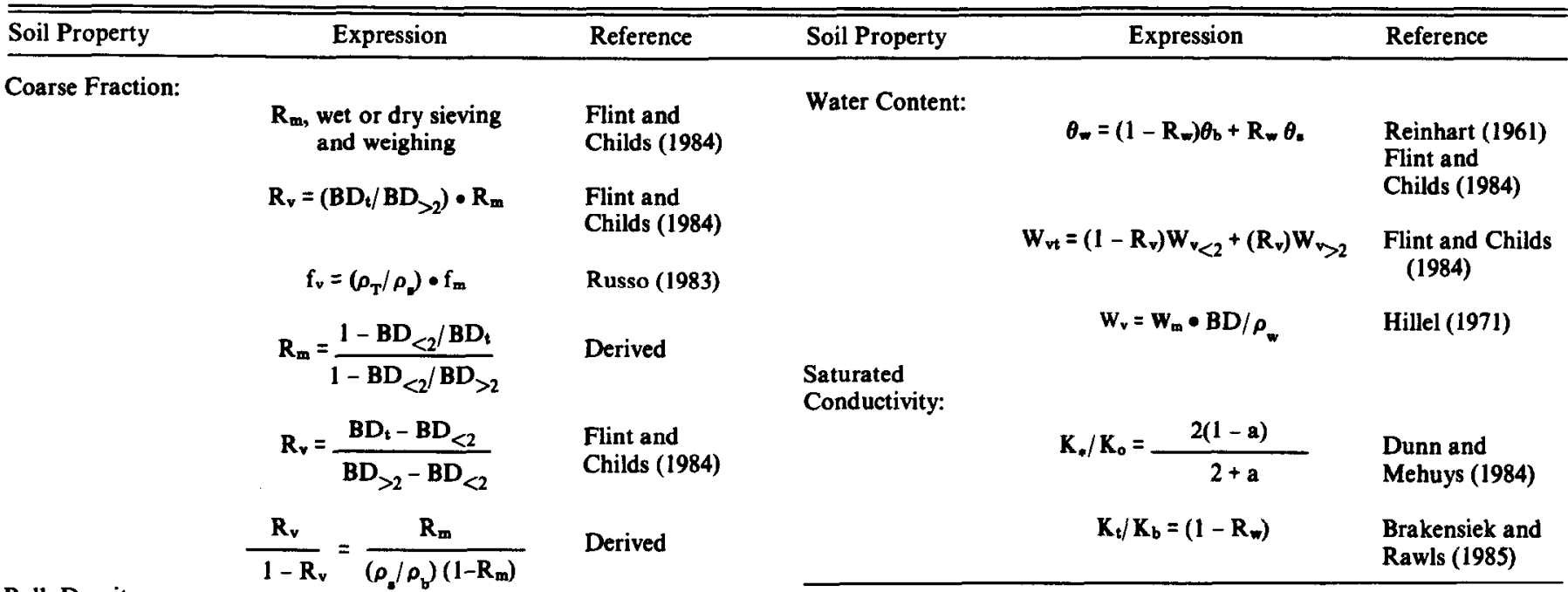

Bulk Density:

$$
\begin{array}{cl}
\rho_{\mathrm{b}}=\rho_{\mathrm{T}} \frac{\left(1-\mathrm{f}_{\mathrm{m}}\right)}{\left(1-f_{\mathrm{v}}\right)} & \text { Russo (1983) } \\
B D_{<2}=B D_{\mathrm{t}} \frac{\left(1-\mathrm{R}_{\mathrm{m}}\right)}{\left(1-\mathrm{R}_{\mathrm{v}}\right)} & \begin{array}{l}
\text { Flint and } \\
\text { Childs (1984) }
\end{array} \\
\rho_{\mathrm{T}}=\left[\mathrm{f}_{\mathrm{m} / \rho_{\mathrm{i}}}+\frac{\left(1-\mathrm{f}_{\mathrm{m}}\right)}{\rho_{\mathrm{b}}}\right]^{-1} & \text { Russo (1983) }
\end{array}
$$

\section{$a, f_{v}, R_{v}=$ Coarse fraction $(>2 \mathrm{~mm})$ by volume}

$\mathrm{d}_{(\mathrm{S}}+\mathrm{A}_{h} \rho_{\mathrm{T}}, \mathrm{BD}_{\mathrm{t}}=$ Bulk density of field bulk soil

$\mathrm{d}_{\mathrm{A}}, \rho_{,} \mathrm{BD}_{>2}=$ Bulk density of coarse fraction $(>2 \mathrm{~mm})$

( $1-W), X_{w}, f_{m}, R_{m}=$ Coarse fraction by weight

$d_{m}, \rho_{b}, B D_{<2}=$ Bulk density of fine fraction $(<2 \mathrm{~mm})$

$P_{>2}=$ Total porosity of coarse fraction

$\mathbf{P D}_{>2}=$ Particle density of coarse fraction

$W_{w}, \theta_{w}=$ Total field water content by volume

$\mathrm{W}_{\mathrm{v}<2}, \theta_{\mathrm{b}}=$ Water content of fine fraction by volume

$w_{v>2} \theta_{0}=$ Water content of coarse fraction by volume

$\mathbf{W}_{\mathrm{m}<2}=$ Water content of fine fraction by weight

$K_{\text {, }}, \mathbf{K}_{\mathbf{t}}=$ Saturated conductivity of bulk soil

$K_{o}, K_{b}=$ Saturated condutivity of fine fraction

$\rho_{w}=$ Density of water

$$
\begin{aligned}
& d_{(s+A)}=\left[\frac{1-X_{w}}{d_{s}} \frac{X_{w}}{d_{A}}\right]^{-1} \quad \text { Berger (1976) } \\
& \rho_{T}=\left(1-f_{v}\right) \rho_{b}+\left(f_{v}\right) \rho_{g} \quad \text { Russo (1983) } \\
& \mathbf{B D}_{\mathbf{t}}=\mathrm{BD}_{<2}+\mathbf{R}_{\mathrm{v}}\left(\mathrm{BD}_{>2}-\mathrm{BD}_{<2}\right) \quad \text { Flint and Childs }
\end{aligned}
$$

$$
\mathrm{BD}_{>2}=\left(1-\mathrm{P}_{>2}\right) \mathrm{PD} \mathrm{P}_{>2} \quad \text { Flint and Childs }
$$

$\rho_{\mathfrak{t}}, \mathrm{BD}_{\mathrm{t}}$ Irregular Hole Bulk Density Sampler

Flint and Childs (1984)

Russo (1983)

Cunningham and

Matelski (1968) 
were developed by assuming that the soil and rock fraction are each made up of porosity and solids on a mass or volume basis. An excellent discussion for the soil fraction alone is presented by Hillel (1971). At the end of Table 1, the symbols are defined corresponding to the key publications referenced since they are not standard.

\section{References On Stony Soils}

Berger, Eli. 1976. Partitioning the parameters of stony soils important in moisture determinations into their constituents. Plant and Soil. 44:201-207.

Brakensiek, D.L., W.J. Rawls, and G.R. Stephenson. 1985. Determining the saturated hydraulic conductivity of a soil containing rock fragments. Soil Sci. Soc. Amer. Journal 50:834-835.

Cunningham, R.L., and R.P. Matelski. 1968. Bulk density measurements on certain soils high in coarse fragments. Soil Sci. Soc. Amer. Proc. 32:109-111.

Hillel, Daniel. 1971. Soil and water: physical principles and processes. Academia Press, New York and London.
Mehuys, G.R., L.H. Stolzy, J. Letey, and L.V. Weeks. 1975. Effect of stones on the hydraulic conductivity of relatively dry desert soils. Soil Sci. Soc. Amer. Proc. 39:37-42.

Reinhart, K.G. 1961. The problem of stones in soil-moisture measurement. Soil Sci. Soc. Amer. Proc. 25:268-270.

Russo, David. 1983. Leaching characteristics of a stony desert soil. Soil Sci. Soc. Amer. J. 47:431-438.

The following are in Soil Sci. Soc. of Amer. Spec. Publ. No. 13, "Erosion and Productivity of Soils Containing Rock Fragments," edited by J.D. Nichols, P.L. Brown, and W.J. Grant. 1984.

Dunn, A.J. and G.R. Mehuys. Relationship between gravel content of soils and saturated hydraulic conductivity in laboratory tests, p. 55-64.

Flint, A.L., and S. Childs. Physical properties of rock fragments and their effect on available water in skeletal soils, p. 91-103.

Miller, F.T., and R.L. Guthrie. Classification and distribution of soils containing rock fragments in the United States, p. 1-6. 